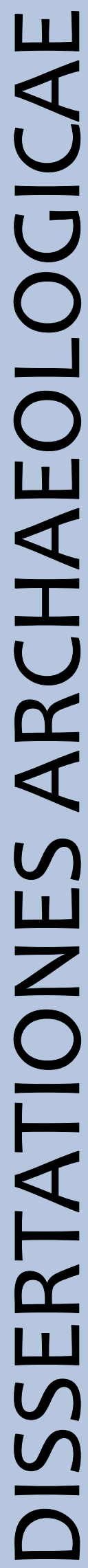

ex Instituto Archaeologico Universitatis de Rolando Eötvös nominatae
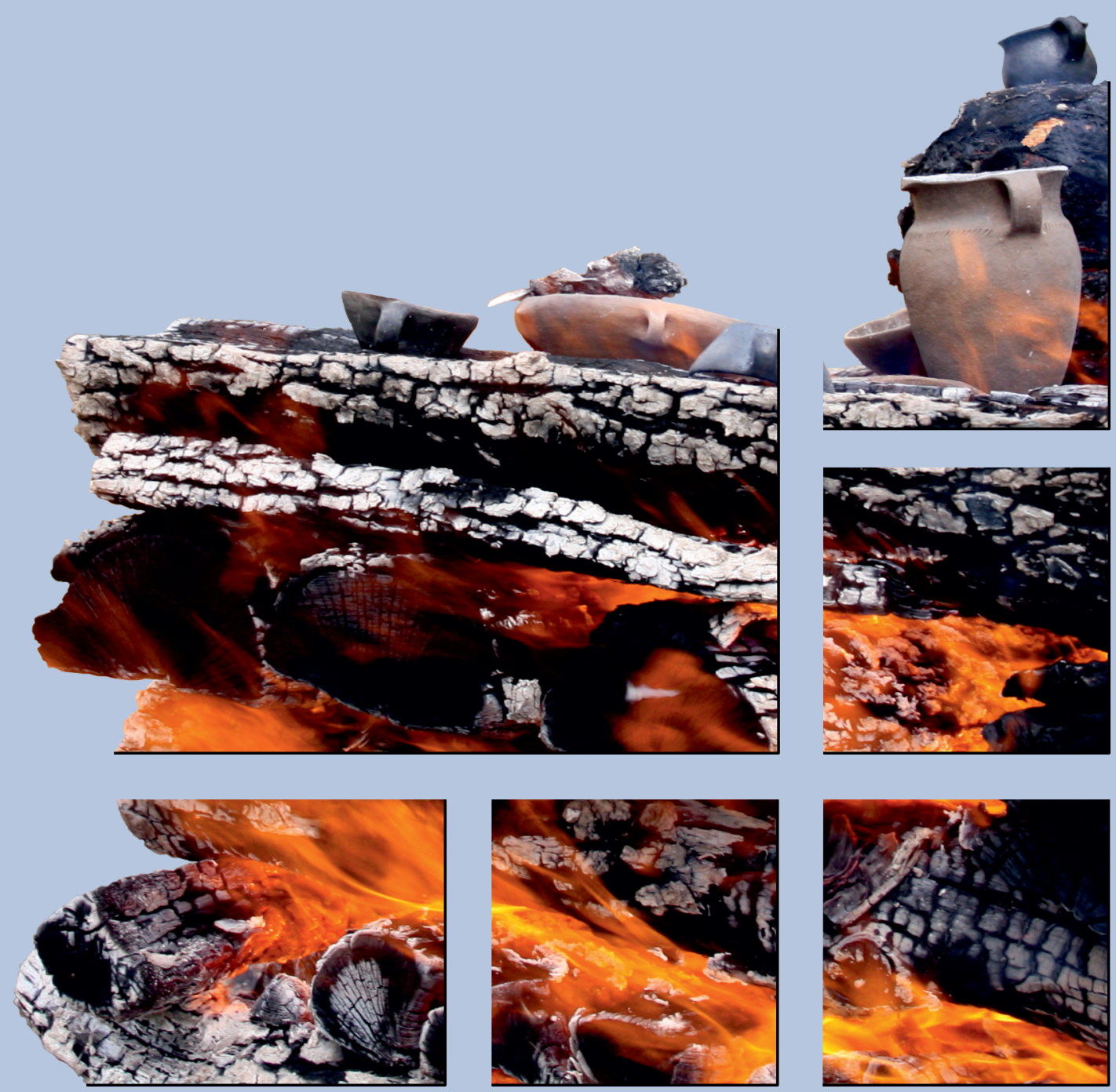

$$
\text { Ser。 3. No } 0_{0} \sigma_{0} \mid 2018
$$




\section{Dissertationes Archaeologicae ex Instituto Archaeologico}

Universitatis de Rolando Eötvös nominatae Ser. 3. No. 6.

Budapest 2018 


\section{Dissertationes Archaeologicae ex Instituto Archaeologico}

Universitatis de Rolando Eötvös nominatae Ser. 3. No. 6.

Editor-in-chief:

DÁvid BARTUS

Editorial board:

LÁsZló BARTOSIEWICZ

LÁSZLÓ BORHY

ZOLTÁN CZAJLIK

ISTVÁN FELD

GÁBOR KALLA

PÁL RACZKY

MiKLÓS SZABÓ

Tivadar Vida

Technical editor:

GÁBOR VÁcZI

Proofreading:

ZsófIA KondÉ

SzILVIA BARTUS-SzÖLLősI

Aviable online at http://dissarch.elte.hu

Contact: dissarch@btk.elte.hu

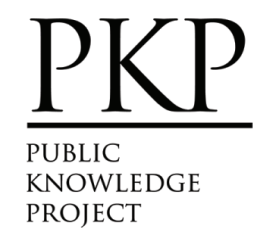

๑ E Eötvös Loránd University, Institute of Archaeological Sciences

Layout and cover design: Gábor Váczi

Budapest 2018 


\section{CONTENTS}

Zsolt Mester

In memoriam facques Tixier (1925-2018)

\section{ARTICLES}

Katalin SEBőK

On the possibilities of interpreting Neolithic pottery - Az újkökori kerámia értelmezési lehetőségeiről

András FüZESI - Pál RACZKY

Öcsöd-Kováshalom. Potscape of a Late Neolithic site in the Tisza region

Katalin SEBőK - Norbert FARAgó

Theory into practice: basic connections and stylistic affiliations of the Late Neolithic settlement at Pusztataskony-Ledence 1

Eszter Solnay

Early Copper Age Graves from Polgár-Nagy-Kasziba

László GuCsi - Nóra Szabó

Examination and possible interpretations of a Middle Bronze Age structured deposition

Kristóf FÜLÖP

Why is it so rare and random to find pyre sites? Two cremation experiments to understand the characteristics of pyre sites and their investigational possibilities

Gábor János TARBAY

"Looted Warriors" from Eastern Europe

Péter MogYoRós

Pre-Scythian burial in Tiszakürt

Szilvia JoHÁczi

A New Method in the Attribution? Attempts of the Employment of Geometric Morphometrics in the Attribution of Late Archaic Attic Lekythoi 
The Roman aqueduct of Brigetio

Lajos JuHÁsz

A republican plated denarius from Aquincum

Barbara HAJDU

Terra sigillata from the territory of the civil town of Brigetio

Krisztina HoppÁL - István VIDA - Shinatria AdHityatAma - Lu Yahui 461

'All that glitters is not Roman'. Roman coins discovered in East Java, Indonesia.

A study on new data with an overview on other coins discovered beyond India

\section{FIELD REPORTS}

Zsolt MESTER - Ferenc CSERPÁK - Norbert FARAGÓ

Preliminary report on the excavation at Andornaktálya-Marinka in 2018

Kristóf FÜLÖP - Denisa M. LÖNHARDT - Nóra SZABÓ - Gábor VÁcZI

Preliminary report on the excavation of the site Tiszakürt-Zsilke-tanya

Bence Simon - Szilvia JohÁcZI - Zita KIS

Short report on a rescue excavation of a prehistoric and Árpádian Age site near Tura

(Pest County, Hungary)

Zoltán CzAJlik - Katalin NovinszKi-Groma - László RupNIK - András BöDőcs - et al. 527

Archaeological investigations on the Süttö plateau in 2018

Dávid BARTus - László BORHY - Szilvia JoHÁczi - Emese SzÁMADó

Short report on the excavations in the legionary fortress of Brigetio (2017-2018)

Bence Simon - Szilvia JoháczI

Short report on the rescue excavations in the Roman Age Barbaricum near Abony

(Pest County, Hungary)

Szabolcs Balázs NAGY

Recent excavations at the medieval castle of Bánd 


\section{Thesis Abstracts}

Rita JENEY

Lost Collection from a Lost River: Interpreting Sir Aurel Stein's "Sarasvatī Tour" in the History of South Asian Archaeology

István VIDA

The Chronology of the Marcomannic-Sarmatian wars. The Danubian wars of Marcus Aurelius in the light of numismatics

Zsófia MASEK

Settlement History of the Middle Tisza Region in the $4^{\text {th }}-6^{\text {th }}$ centuries AD.

According to the Evaluation of the Material from Rákóczifalva-Bagi-földek 5-8-8A sites

Alpár Doвоs

Transformations of the human communities in the eastern part of the Carpathian Basin between the middle of the $5^{\text {th }}$ and $7^{\text {th }}$ century. Row-grave cemeteries in Transylvania, Partium and Banat 


\title{
Preliminary report on the excavation of the site Tiszakürt-Zsilke-tanya
}

\author{
KRISTÓF FÜLÖP \\ Institute of Archaeological Sciences \\ Eötvös Loránd University \\ fulopkr14@gmail.com
}

\author{
NóRA SzABÓ \\ Institute of Archaeological Sciences \\ Eötvös Loránd University \\ szabonori91@gmail.com
}

\author{
DENISA M. LÖNHARDT \\ Institute of Archaeological Sciences \\ Eötvös Loránd University \\ lonhardt.denisa@gmail.com \\ GÁBOR VÁCZI \\ Institute of Archaeological Sciences \\ Eötvös Loránd University \\ vaczigabor@gmail.com
}

\begin{abstract}
Colleagues of the Institute of Archaeological Sciences of the Eötvös Loránd University performed a rescue excavation at the site of Tiszakürt-Zsilke-tanya in 2018, within the series of excavations preceding the construction of the M44 motorway. Neolithic, Sarmatian, and Avar Age settlement sections and burials came to light on the hills situated on the left bank of the Tisza River. This preliminary report presents their most important finds and phenomena.
\end{abstract}

\section{Introduction}

We carried out a rescue excavation at the archaeological site of Tiszakürt-Zsilke-tanya in advance of the construction of the M44 motorway in 2018. ${ }^{1}$ The excavated 5.8-hectare surface covered the area of the planned intersections on both sides of the M44 motorway. The site is situated west of Tiszakürt, in the western neighbourhood of the sand hill of Tiszakürt named Nagysziget, at the northern end of a north-western - south-eastern-oriented sandbank that divides into two branches. It is bordered by the one-time floodplain of the Tisza from the north, the east and the west. Based on surface finds and aerial photographs, the southern edge of the site may be 350-400 metres away from the excavated area (Fig. 1).

The surface of the excavation was strongly eroded; due to the agricultural activities the onetime topsoil of the two hills slid into the valley in between, thus forming a $60-70-\mathrm{cm}$-deep, easily distinguishable filling above the original, 30-40-cm-deep surface soil. Consequently, the archaeological features could be recognized more difficultly, and only in a great depth in the valley, while soil cultivation caused more damage to the shallowly situated burials, buildings, and fireplaces on the hills.

1 Entrusted by the Budavári Kft, the Institute of Archaeological Sciences of the Eötvös Loránd University carried out the excavation. Staff of the excavation: Gábor V. Szabó project leader; Gábor Váczi leader of the excavation; Kristóf Fülöp, András Füzesi, Polett Kósa, Denisa M. Lönhardt, Eszter Rákos, Eszter Soós, Nóra Szabó, Márton Szilágyi archaeologists. 


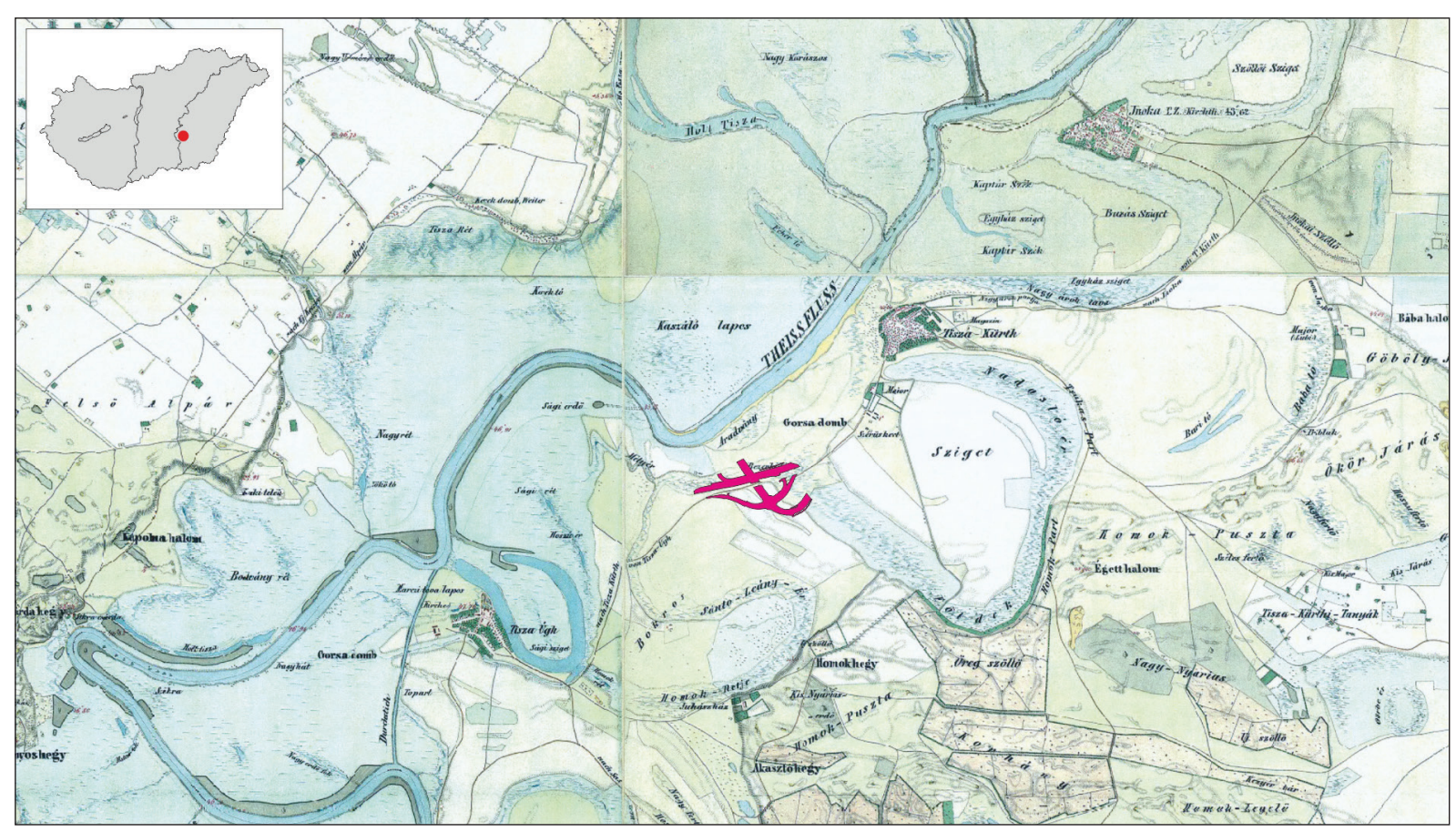

Fig. 1. Geographical position of the archaeological site Tiszakürt-Zsilke-tanya.

The eastern hill was the most intensely inhabited area of the site. The three-fourths of the altogether 1750 unearthed archaeological features came to light here. Both hills were inhabited and used during three historical periods: in the Middle Neolithic, in the second half of the Sarmatian period, and the early and late phases of the Avar period. The western hill gave place primarily to features dating from the Middle Neolithic, and sporadic elements of the Sarmatian settlement appeared here, too. At the northern edge of the hill near the Tisza, we also found four burials dating from the late Avar period. On the eastern hill, we revealed the archaeological records of all the three above-mentioned periods. The Neolithic settlement appeared densely in the northern area of the eastern hill, near the river, while 180-200 metres from the boundary of the former floodplain, there is no trace implying a Neolithic inhabitation. Features of the Sarmatian-period settlement spread over the entire eastern hill, as well as the valley in between the two hills. We excavated a section of a early Avar-period cemetery in the area of the Neolithic buildings situated on a plateau running along the eastern side of the eastern hill. On the opposite, western side of the hill, a row of buildings and some pits indicated the late Avar-period inhabitation in this territory.

\section{Middle Neolithic}

The features of the Middle Neolithic settlement (Alföld Linear Pottery culture) were concentrated in two areas, on the eastern and western hills (Fig. 2). The site fits well into the settlement network of the Middle Neolithic Tiszazug micro-region. ${ }^{2}$ Most of the features are usually round storage and waste pits of various size, or large and long (Langsgrube) or amorphous clay pits. Most of them contained pottery, daub, animal bone, and often a large amount of shellfish, and sporadic stone material. In one case, a structured deposition of two small and intact vessels (1207/1279) was unearthed from 60 centimetres deep, on the northern edge of a 
Middle Neolithic period

Sarmatian period

Avar period

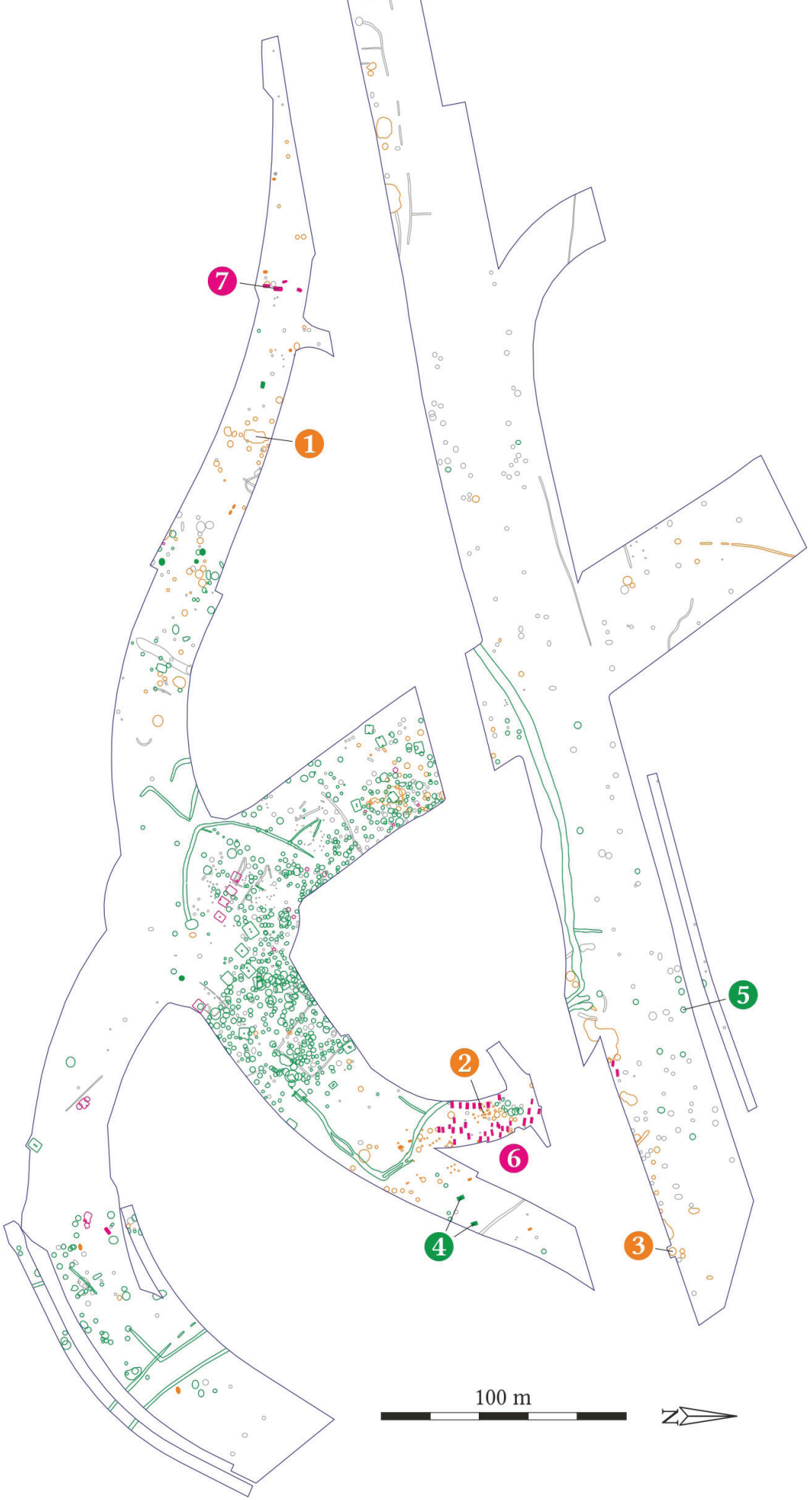

Fig. 2. Map of the archaeological site Tiszakürt-Zsilke-tanya archaeological site. 1 - the Neolithic Langsgrube with the vessel deposit (1207/1279), 2 - the Neolithic northwest-southeast oriented building with triple, longitudinal rows of posts, 3 - the Neolithic tube-like well (1442/1573), 4 - Sarmatian burials on the periphery, 5 - Sarmatian well (1493/1630), 6 - the early Avar-period cemetery, 7 - late Avar-period graves. 
5.3-meter-long Langsgrube (Fig. 2.1, Fig. 3.1-3). Although one tilted, the cups originally stood next to each other. The mouth of both vessels was covered by a deliberately broken vessel fragment. One cup was filled with red ochre, while the other probably with some organic material, as indicated by the organic residue found at the bottom of the vessel. On the one hand, the depot points to the special function of the Langsgrube, besides its role in clay acquisition, while on the other hand, it stresses the symbolic importance of ochre, that plays a peculiar role in burials (see below) and in everyday life. ${ }^{3}$

The round or oval, oblong, 10-50-cm-deep postholes were found on the eastern hill, without exception. They provide clear evidence of at least two or three timber-framed buildings, though their exact structure is uncertain due to their missing postholes. Only the structure of the northern building can be reconstructed. A simple, northwest-southeast-oriented building with triple, longitudinal rows of posts can be outlined (Fig. 2.2), which fits well into the spectrum and development of the various house plans observed on the Middle Neolithic Great Hungarian Plain. ${ }^{4}$
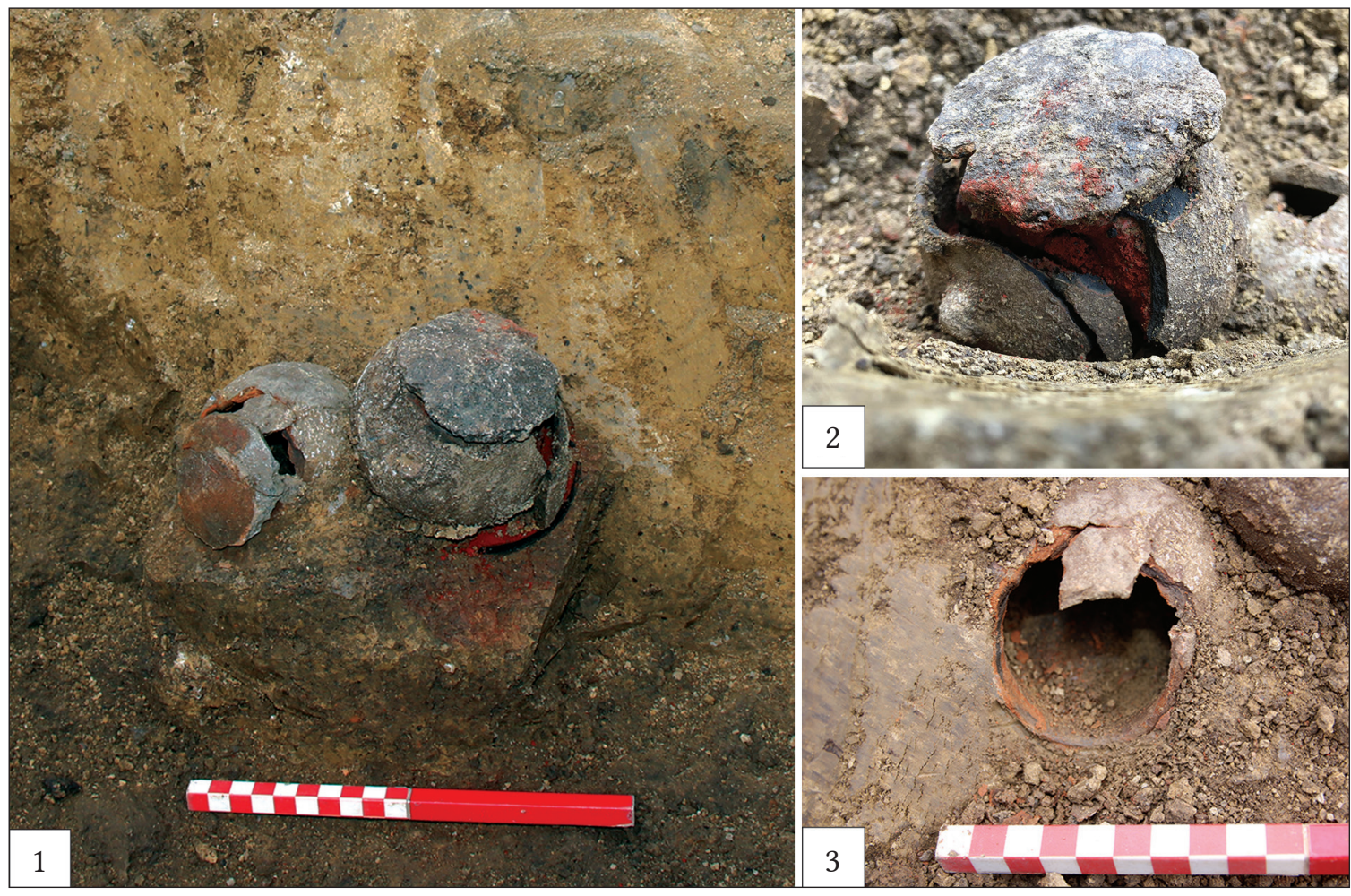

Fig. 3. 1 - The deposition of two small and intact vessels, 2 - the first cup filled with red ochre, 3 - the second cup probably filled with some organic material.

One of the most fascinating features of the site was the so-called tube-like well (Stammbrunnen) $(1442 / 1573)$ found on the north-eastern edge of the settlement situated on the eastern hill (Fig. 2.3). In addition to the preserved wooden structure and its unique technological traits, the significance of the feature is further enhanced by the fact that this well is only the third Neolithic tube-like well - besides the Sajószentpéter ${ }^{5}$ and Berettyóúffalu ${ }^{6}$ wells - discovered in Hungary. 
Like the majority of prehistoric wells, ${ }^{7}$ it was built at the edge of the settlement at a lower elevation, thus minimalizing the time and energy investment into digging, and the possibility of the well drying out. The water replenishment of proper quantity and spouting speed was provided by the nearby Tisza River. The wooden structure, uncovered at a depth of $250-260 \mathrm{~cm}$, was placed in the centre of the large $(365 \times 345 \mathrm{~cm})$, round, and vertical well shaft. Due to the spouting groundwater and the heavily muddy and clayey infill, we could unearth a $115-125 \mathrm{~cm}$ section of the wooden lining to a depth of $375 \mathrm{~cm}$ (Fig. 4.1-2). However, despite the circumstances, we were able to document its unique technology. The well structure is manufactured of several wooden rings carefully placed on each other, instead of one large trunk. An at least 90-100-cm-long, slightly thinner, broadening ring was joined to the lower, approximately $30 \mathrm{~cm}$ long wooden ring. Similarly to ethnographic data, ${ }^{8}$ the upper, fully excavated ring was formed by cutting or splitting the trunk into two parts and carving out the interior parts. The surface of each piece was thoroughly worked and no traces of bark could be observed. The two pieces were then fastened together with wattles driven through the holes carved at the bottom (Fig. 4.3).
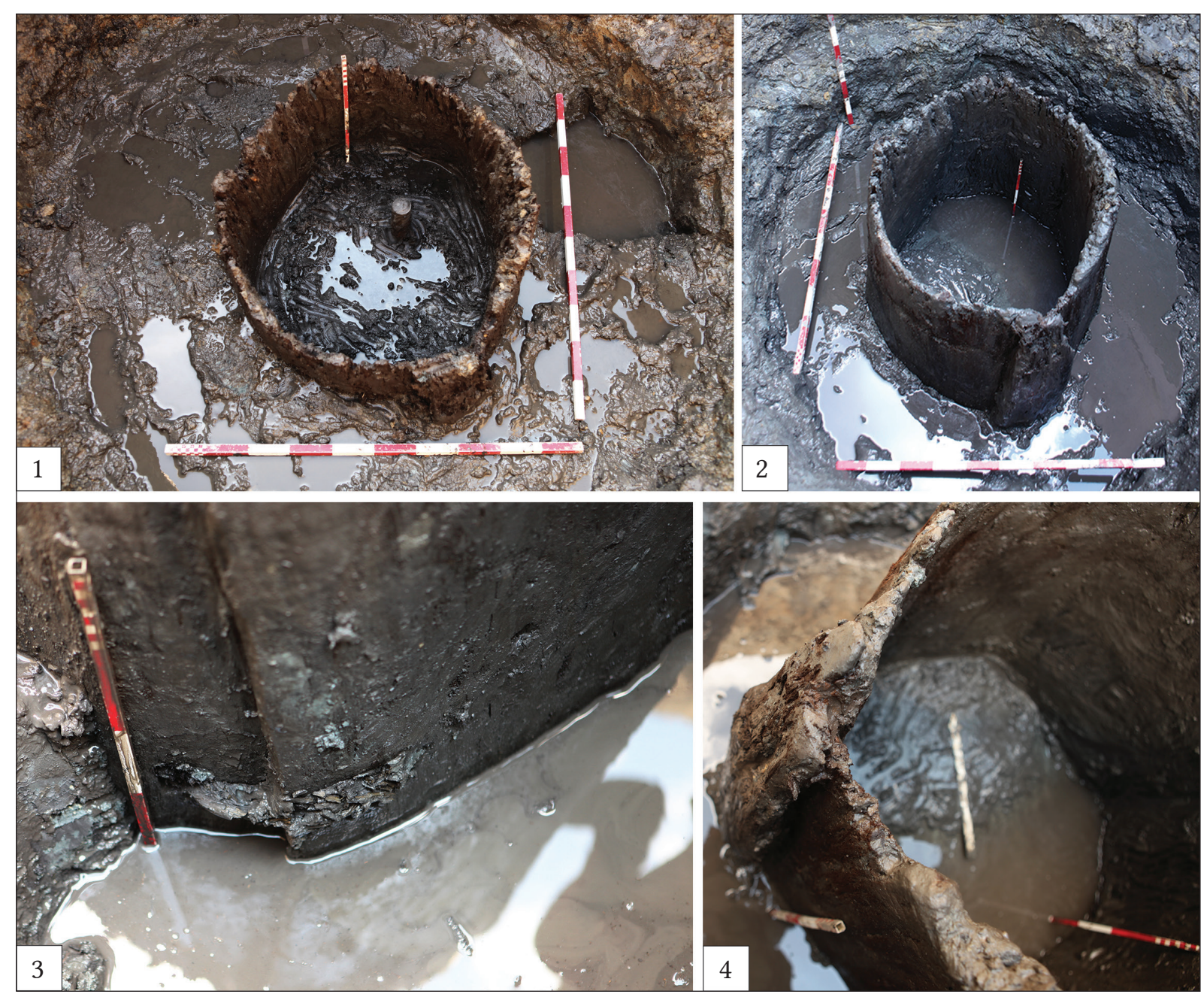

Fig. 4. 1 - the partially unearthed tube-like well, 2 - the completely uncovered upper wooden ring, 3 - the fastening of the two halves with wattles driven through holes carved at the bottom of the wooden ring, 4 - the board struck into the bottom of the shaft in the western side of the well.

8 GöNCZI 1905, 8. 
Finally, for a greater stability, two 20-30-cm-wide boards tightly fitted to the rings were sunk into the ground at the bottom of the shaft, at the joints of the two halves (Fig. 4.2-4). In contrast, the well uncovered in Berettyóújfalu was made from one hollowed trunk of a diameter of 80-90 cm. ${ }^{9}$ The $90-\mathrm{cm}$-diameter oak trunk of Sajószentpéter was split into four parts, and the pieces were fastened together with thick wattles, in the same way as in Tiszakürt. ${ }^{10}$ The complex and diverse technology of all three Hungarian Middle Neolithic tube-like wells fits well into the various type of long-lasting, 'professional' wells constructed of a solid wood structure. The contemporary wells throughout Europe clearly reflect the expert carpentry skills and the inherited and continuously expanding knowledge of raw materials and technologies. ${ }^{11}$

Only a small amount of pottery and a few wood waste were found in the well's infill. A 55-cmlong section of pollen sample was taken from the well's layers, and soil samples were also collected from every 20-30 centimetres. The complete removal of the wooden lining was not possible due to the condition of the lining and the difficult circumstances.

A total of 17 burials were found at the site (Fig. 2). Most of the graves were scattered within the settlement singly or in small groups. Similarly to other contemporaneous burials, ${ }^{12}$ several graves had a close relationship with houses, and most of them were aligned with the reconstructed northwest-southeast oriented building. Some graves, on the other hand, were placed a little further from the settlement, while two graves were far away on the southern part of the eastern hill. It is possible that these two burials once belonged to a farmstead destroyed by the sand mine. However, the case, that one of them is the only burial in which the deceased was laid on its right side, may refer to their special situation, although other mortuary elements do not differ from the general funeral rite outlined in the site.

The graves were shallow, thus many of them have been disturbed to a greater or lesser extent. The one-time oval grave pit could be rarely documented. All deceased, except for the above-mentioned burial, was laid on the left side in a crouched position. This dominance fits well into the rite of positioning irrespectively of status in the Middle Neolithic. ${ }^{13}$ The left hand was often folded under or in front of the head. In contrast, the body orientation does not reflect a uniform picture. We could observe five different orientations of the skeletons.

According to the general mortuary practice of the period, the number of the grave goods is low. ${ }^{14}$ There was no trace of any grave goods in nine burials. In five cases, the deceased was accompanied by only one artefact (two small vessels, one grinding stone, and two large Spondylus beads). Only one grave contained two objects, a lump of ochre and a shellfish. In the richest burial (1021/1082), a total of nine various shaped and small or medium-sized stone and Spondylus beads scattered partially in a secondary position. The special position of this grave is indicated by the fact that the woman was buried with her newborn. Furthermore, it is the only burial where the body was not laid into a grave pit but onto the bottom of an oval pit. In two other graves, we also found large, cylindrical Spondylus beads characteristic of the Middle Neolithic (Fig. 5.1-2). ${ }^{15}$ An intriguing burial was found close to the buildings (1385/1514)

9 FÜZESI et al. 2015, 226.

10 KirÁly - Tóth 2015, 214.

11 Tegel et al. 2012; WeIner 2012; FÜlöP, in press.

12 DomboróczKi 2009.

13 Whittle et al. 2013, 61, 66, 75, 89.

14 Oravecz 1998-1999, 56-58; Oross - Marton 2012, 269-277.

15 SiKLósi - Csengeri 2011, 49, Tab. 1. 


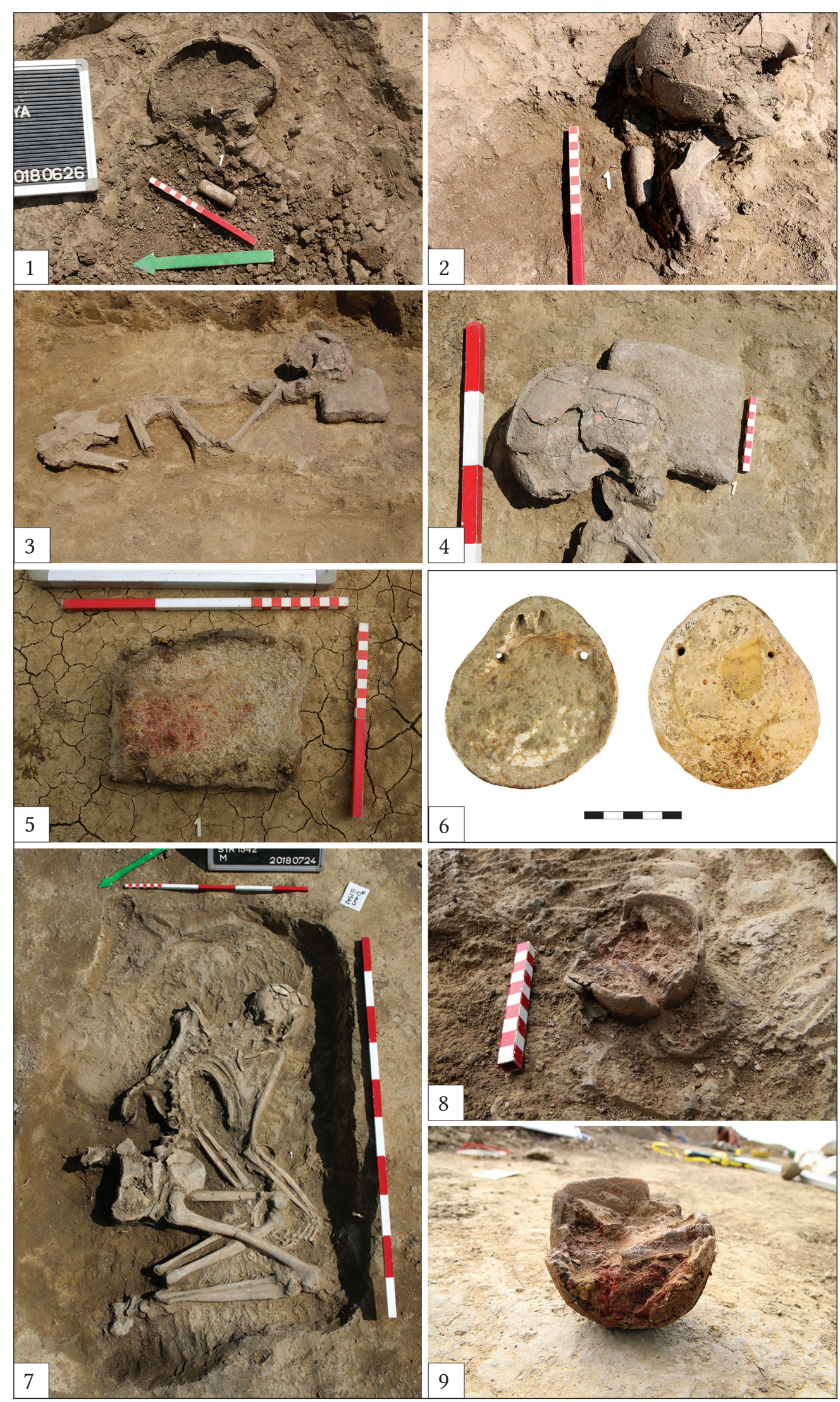

Fig. 5. 1-2 - the large, cylindrical Spondylus beads of Grave 1212/1280 and 1057/1118 found around the neck, 3-4 - the deceased with a grinding stone under his head (1385/1514), 5 - the red ochre coated surface of the grinding stone, 6 - the sporadic Spondylus pendant found on the western hill, 7 - burial 1413/1542 with the vessel under the right elbow, 8-9 - the small cup filled with red ochre. 
on the eastern hill. A grinding stone was placed upside down under the head of the deceased, who was laid on the left side in a crouched position (Fig. 5.3-4). The grinding stone was probably used for crushing ochre, as it is indicated by traces of ochre on its surface (Fig. 5.5). Similar processing tools are known from contemporaneous burials and settlements. ${ }^{16}$ Besides the above-mentioned vessel depot, the symbolic significance of ochre is emphasized by other burials as well. A skull was painted red in one grave. A single ochre lump was deposited into another grave as a grave good. In the burial 1413/1542, a small vessel filled with red ochre was placed under the right elbow of the deceased (Fig. 5.7-9). A similar small cup with ochre was also discovered in one of the graves of the nearby site of Cserkeszollo-Kisasszony-szőlő III. ${ }^{17}$

A Spondylus pendant was also found on the western hill as a stray find (Fig. 5.6). In general, this type of jewellery appears in other contemporaneous cemeteries as a characteristic grave good. ${ }^{18}$ Consequently, this piece most likely belonged to a grave, which was destroyed by the intensive agriculture.

\section{Sarmatian Period $\left(2^{\text {nd }}-4^{\text {th }}\right.$ century AD)}

A large number of the unearthed archaeological features can be dated to the $2^{\text {nd }}-4^{\text {th }}$ centuries $\mathrm{AD}$. The settlement features were dominated by pits and beehive-shaped storage pits, but we also uncovered a few open-air ovens and clusters of smoking pits (Fig. 2). Furthermore, in the course of the excavation, we described 18 features that could be dated to this period as "building" on the basis of their size and form. The semi-subterranean rectangular buildings had different structures (with one or two post-holes on their long axis), and only three of them had fireplaces inside. In connection with the buildings, we must mention a type of feature that was generally rectangular with no record of an entrance or a posthole, suggesting that they had functioned as cellar-like storage facilities.
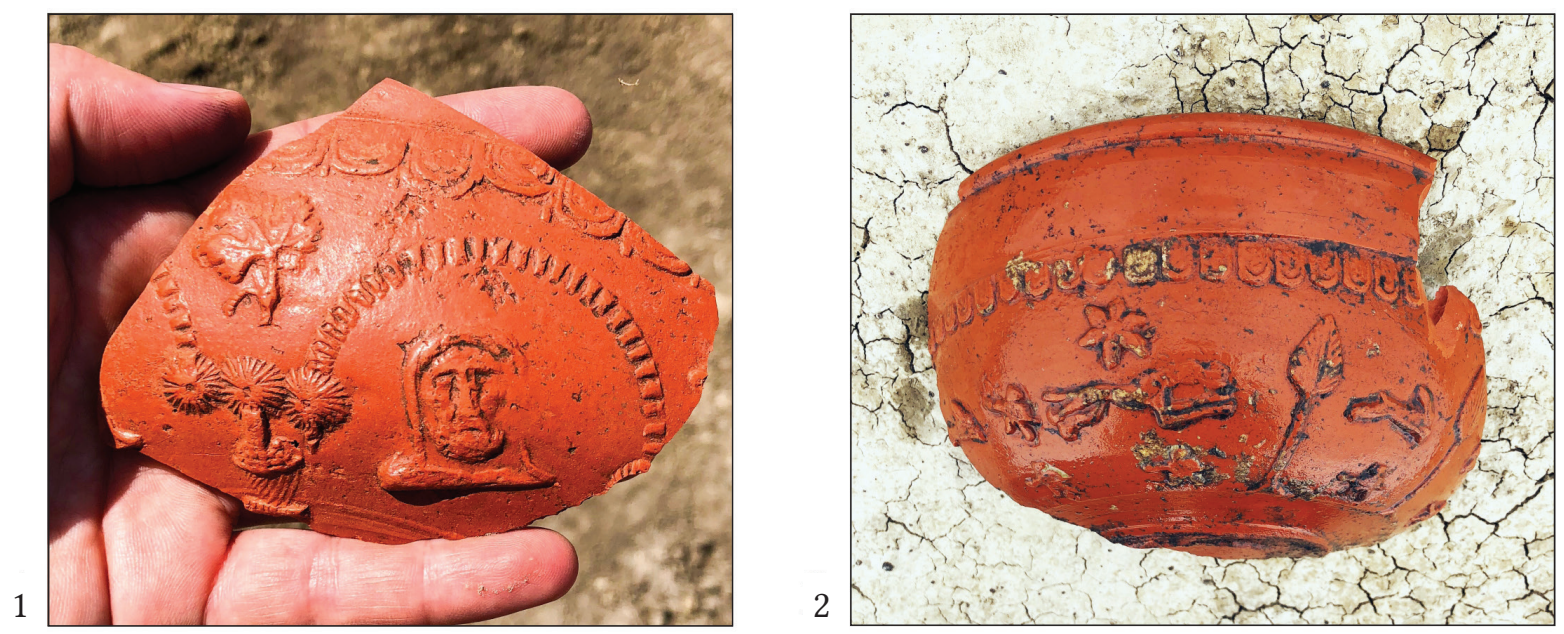

Fig 6.1 - product of Westerndorf, produced by the workshop of Onniorix, 2 - product of Rheinzaberg, Victor III Severan period.

16 Meller et al. 2013, 148-151, Liste 2.

17 Szilágyi et al. 2017, 397, Fig. 4.

18 ORAVECZ 1998-1999. 
The find material recovered from the settlement is relatively rich $;{ }^{19}$ mostly animal bones and pottery, the latter even including a few terra sigillata fragments.

We found terra sigillata sherds (Fig. 6.1-2) in the filling of features spread all over the entire settlement area, with no particular concentration. The terra sigillata material observed during the excavation comes from three production centres: Rheinzabern, Westerndorf and Pfaffenhofen. ${ }^{20}$ Another characteristic feature that was noticed is the occurrence of numerous fragments of terra sigillata imitations, mostly conical cups and bowls with no decoration, rarely with stamps. On the basis of Roman find material, they may respectively be dated from the second part of $2^{\text {nd }}$ century $\mathrm{AD}$ to the third part of mid- $3^{\text {rd }}$ century AD. ${ }^{21}$

Four of the pits lying among the settlement features contained "thrown" partial human skeletons, such cases, where human remains were dropped into waste pits, were observed in several Sarmatian sites of the Carpathian Basin. ${ }^{22}$

Only three of these burials could undoubtedly be associated with this period (Fig. 2.4). All of them were placed into oblong pits with gently rounded corners. The heavily disturbed skeletons were buried in an extended position, the orientation was south-north in two cases, and west-east in one case. ${ }^{23}$ The grave goods as iron knives, iron fragments, two rectangular prism-shaped beads made of almandine, undecorated circular flat spin-

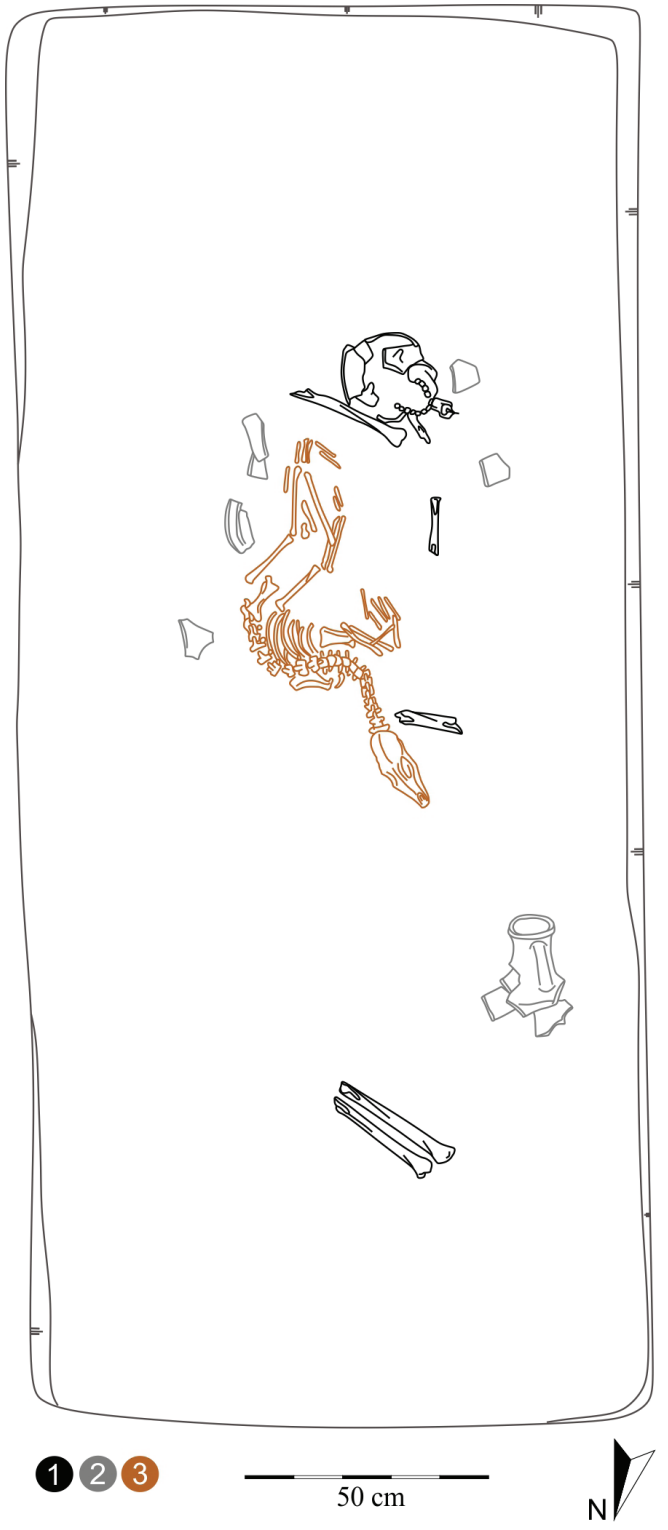

Fig. 7. Sarmatian grave. 1 - human bones, 2 - jug, 3 - dog skeleton.

dle-whorl, were characteristic of the Sarmatian Period. It must be mentioned here, that the dog's skeleton found in the heavily disturbed grave (Fig. 7) cannot be considered as a part of that burial. Moreover, the dog's skeleton was discovered higher, not directly in the actual grave pit. Also it has remained intact whereas the human skeleton was completely mixed up in this grave. No grave goods were found here, only a broken two handled wheel-made jug, below the human skeleton, on the bottom of the feature. From the position of the dog skeleton, it is clear that the animal had been carefully laid, not thrown into the feature.

19 The proportion of stones, metal objects and other finds was also relatively low and no typical features associated with bone manufacturing, pottery or metallurgy were found at the site.

20 GABLER - VADAY 1986, 34-38.

21 GABLER 2012, 123, 126.

22 Istvánovits 1999, 176; Kulcsár 1998, 111.

23 Burials with W-E orientation appear in more extended chronological interval, during the $2^{\text {nd }}-4^{\text {th }}$ centuries AD. (Kulcsár 1998, 21.) 
Dog skeleton findings deserve a special attention, because they appear at several Sarmatian settlements from the very beginning of the period until its end. They are found most often in semi-subterranean buildings, housing pits, kilns, next to the deceased, or in a nearby pit. ${ }^{24}$ They are mostly interpreted as construction sacrifices, or as guardians in the case of natural death. ${ }^{25}$ Atypical funerary situations were documented only in two cases, in which the dog was buried together with human corpses. ${ }^{26}$

Several Sarmatian wells came to light at this settlement, all of them had a rounded or oval upper part, and their size vary from small to very large. Only one of the wells was almost completely excavated (well no. 1493/1630) (Fig. 2.5). Its mouth was rounded, and the shaft wall ran steeply down to a deeper layer. The first plank row of the construction appeared $2 \mathrm{~m}$ deep (Fig. 8). Thereafter, four rows of planks were discovered until the bottom of the well. The split and elaborated planks carved at their both ends and sides were framed by interlocked corner joints.

1
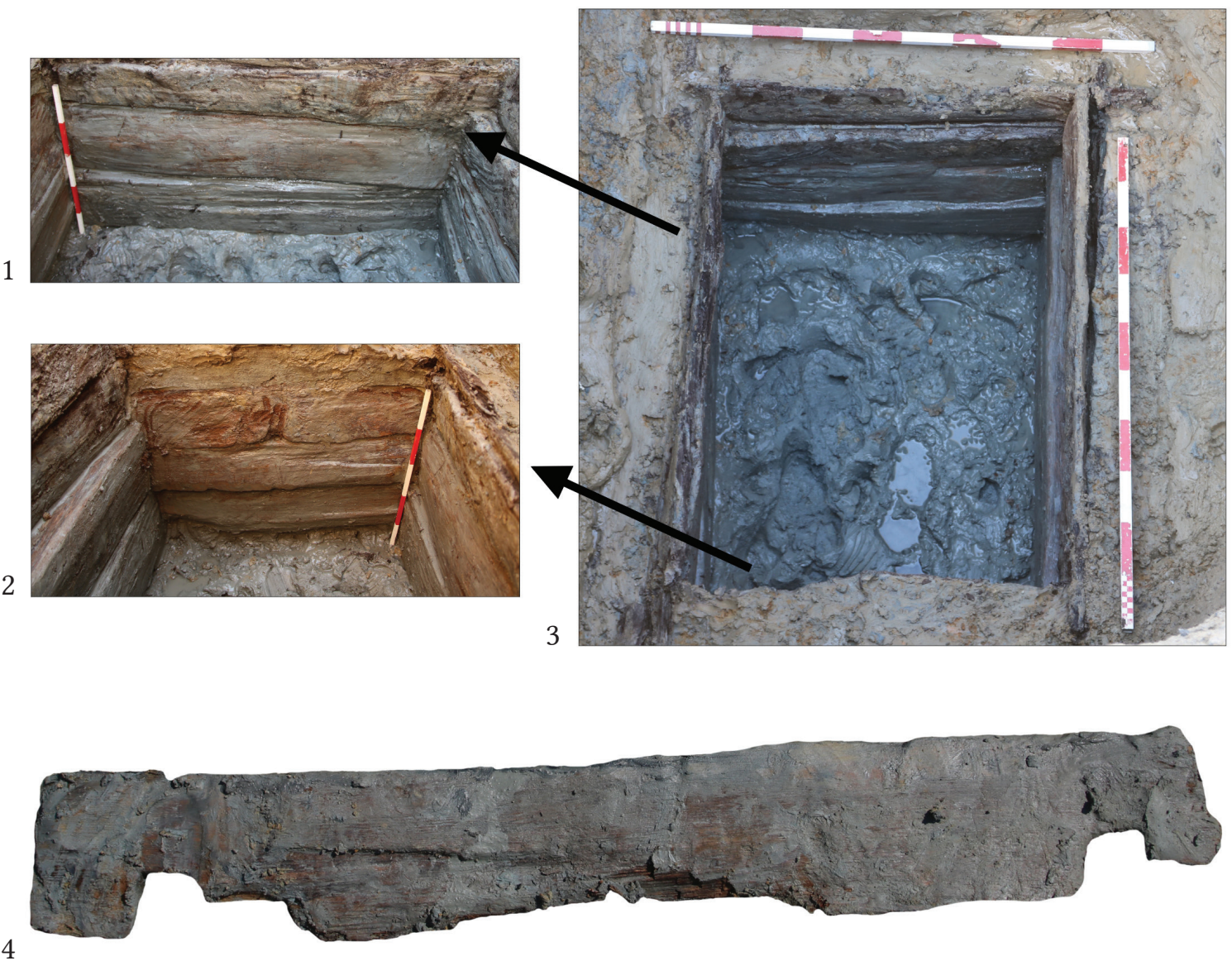

$50 \mathrm{~cm}$

Fig. 8.1 - the southern side of the well, 2 - the western side of the well, 3 - the wooden structure of the well, 4 - a plank from the eastern side of the well.

24 Dog skeletons were found in Feature 118 of Tiszavasvári-Városföldje, Jegyzőtag, Feature 118 of Tiszadob-Sziget and Feature 138 of Dunakeszi-Alagi major. (Istvánovits 2015, 115-116). At Garadna settlement in total $17 \mathrm{dog}$ skeleton were found from storage pits. (CSENGERI - PUSZTAI 2008, 97.)

25 NoHÁlovÁ et al. 2006, 84.

26 At Dunakeszi-Alagi major in a circular Pit 138 an infant was buried with two dogs. (IstVÁNOviTs 1999, 176.). Further, at Tiszaföldvár-Téglagyár in Pit 26/1982 an 10 year old infant was buried with two dogs. (VADAY 1997, 83, Fig. 3) 
The wooden lining had a relatively rectangular shape in the horizontal plane, the upper part measured $96 \times 70 \mathrm{~cm}$, and the lower $100 \times 68 \mathrm{~cm}$. The width of the planks varied between $14-20 \mathrm{~cm}$ and their thickness was $3 \mathrm{~cm}$. Fragments of grey wheel-made pottery were found in its filling. According the wooden structure and the observed technological traits, the well can be classified into the so-called 'timber lined well' type. ${ }^{27}$

The settlement was surrounded by ditches, some of these were undoubtedly defensive, while others functioned as animal pens or as drainage ditches. All of them fits within the Roman Period settlement structure (Fig. 2).

According to the preliminary analysis, the Sarmatian settlement seems to have had a late phase as well (end of the $3^{\text {rd }}$ and the $4^{\text {th }}$ centuries). This is supported by the superposition of a number of Sarmatian features and the wheel-thrown dark grey ceramics with smoothed-in ornaments from a few pits. ${ }^{28}$ Furthermore, the phenomenon of human skeletons found in the waste pits can mostly be dated to the late period..$^{29}$ No signs of destruction are apparent in the features, it seems that the discussed settlement was abandoned in a peaceful way.

\section{Graves from the Avar period}

Graves of a cemetery section represent the early Avar period of the site. 35 graves have come to light in the eastern branch of the excavation area, on the narrow track of a service route (Fig. 2.6). Based on the small size of the excavated surface and the burials found on the northern side of the road, we can expect a cemetery with a large amount of graves yet underground. In the cemetery - comprising north-south-oriented rows of graves -, the grave pits were on an east-western axis, however, the laying of the deceased was not uniform: both east-west and west-east orientation occurred. The first one was more frequent, while the west-east orientation was rarer, and it only applied to five graves. This proportion can be considered general in early Avar-period cemeteries. ${ }^{30}$

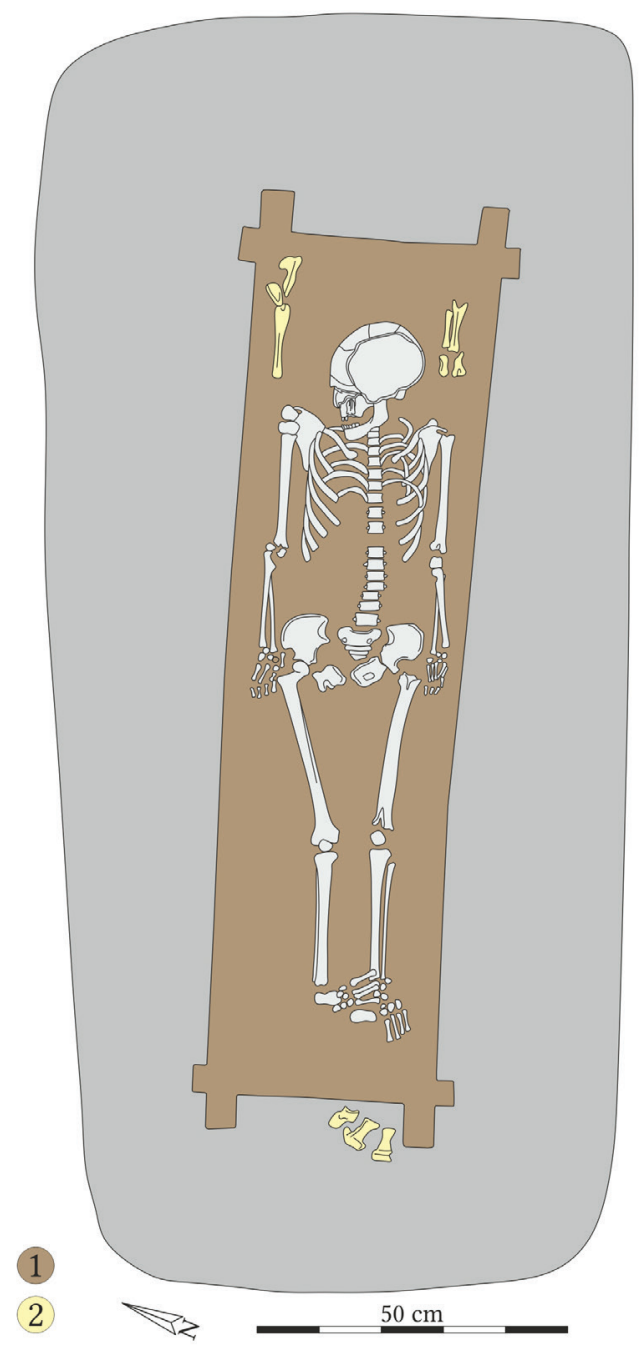

Fig. 9. Traces of an early Avar period coffin burial in Grave 929/987. 1 - coffin, 2 - animal bones.

Agricultural activities affected some of the shallow graves; the skeletons in them were fragmented, and in a poor condition. Traces of a coffin were visible in only one case (Fig. 9). We could record discoloured soil stains marking the one-time wooden planks of the coffin at

30 GuLYÁs - LŐRINCZY 2018, 540. 
the level of laying. The notch-structured planks run over the corners, forming a coffin with a base area of $50 \times 160 \mathrm{~cm}$.

Among the more deeply dug graves, we observed the deposition of partial animals in 21 cases (Fig. 10). Animal bones were laid in two ways; either $40-50 \mathrm{~cm}$ above or at the same level as the deceased. In advance of an archaeozoological analysis we can only conclude that while the bones of larger animals (cattle, horse) came to light above or beside the deceased, those of small ruminants (sheep/goat) were found at the same level the deceased was laid onto. None of the graves contained complete animal skeletons, the animal remains were deposited after the so-called truncating version of skinning. Accordingly, only the skull and the leg bones, split into two at their distal end, were placed into the graves next to the deceased, which was a frequent element of the burial practice in the Trans-Tisza region in the early Avar period. ${ }^{31}$

A skinned horse remain was placed into the burial in one case, remains of a skinned cattle in two cases, and the deceased was covered with a horse skin in three cases. In four cases, we could observe that a sheep/goat was also placed into the grave as a food offering, and the deceased was covered with the skin of another sheep/goat. ${ }^{32}$ The bones placed onto the laying level of the deceased as food offering were not the skull and the limb bones that remained from truncating, but thoracic and lumbar vertebrae. An example for that is a burial with coffin, where the meat offering was deposited outside the coffin (Fig. 9).

Besides partial animal remains, placing ceramic vessels into the graves was also frequent in the Trans-Tisza region during the early Avar period. ${ }^{33}$ We found ceramic vessels in ten graves in the cemetery section of Tiszakürt (Fig. 10). Mostly small pots, and in one case a jar was placed into the graves. According to the burial customs characteristic of this period, the vessels were placed by the head of the deceased in eight cases. ${ }^{34}$ Vessels were found by the feet only in three cases. Grave 1432/1563 differs from the burials of this period and region, since two vessels were deposited by the head of the deceased. In one of the pots, small animal bones indicate that this vessel contained food offerings at the time of the funeral.

Regarding metal artefacts and jewellery, this cemetery section can be considered poor, although we have to mention that the bones of the upper body of four deceased were found in a disturbed position. Most frequently, in the case of eleven graves, we found iron knives and iron buckles around the pelvis. In four cases, the deceased wore a sting of beads on the neck, and four had golden silver and silver earrings. Spindle whorls occurred among the grave goods of four individuals.

Based on the early Avar-period burial found at the northern side of the main road, we assume that further 10-15 graves may be under the embankment of highway M44, which can only be excavated after the breaking up of the presently used road.

Four graves can be dated to the late Avar period, which were separated from the cemetery of the early period even in space, as they came to light $300 \mathrm{~m}$ westwards, on the highest elevation of the western hill (Fig. 2.7). All of these graves were disturbed and robbed.

31 LőRINCZY 2016, 157.

32 The custom of double animal burial could also be observed in the graves of the nearby early Avar-period site of Öcsöd 96: MADARAs 2004, 342.

33 LőRINCZY 2016, 161.

34 Gábor Lőrinczy also observed a similar proportion of occurrence: LőRINCZY 1998, 352. 


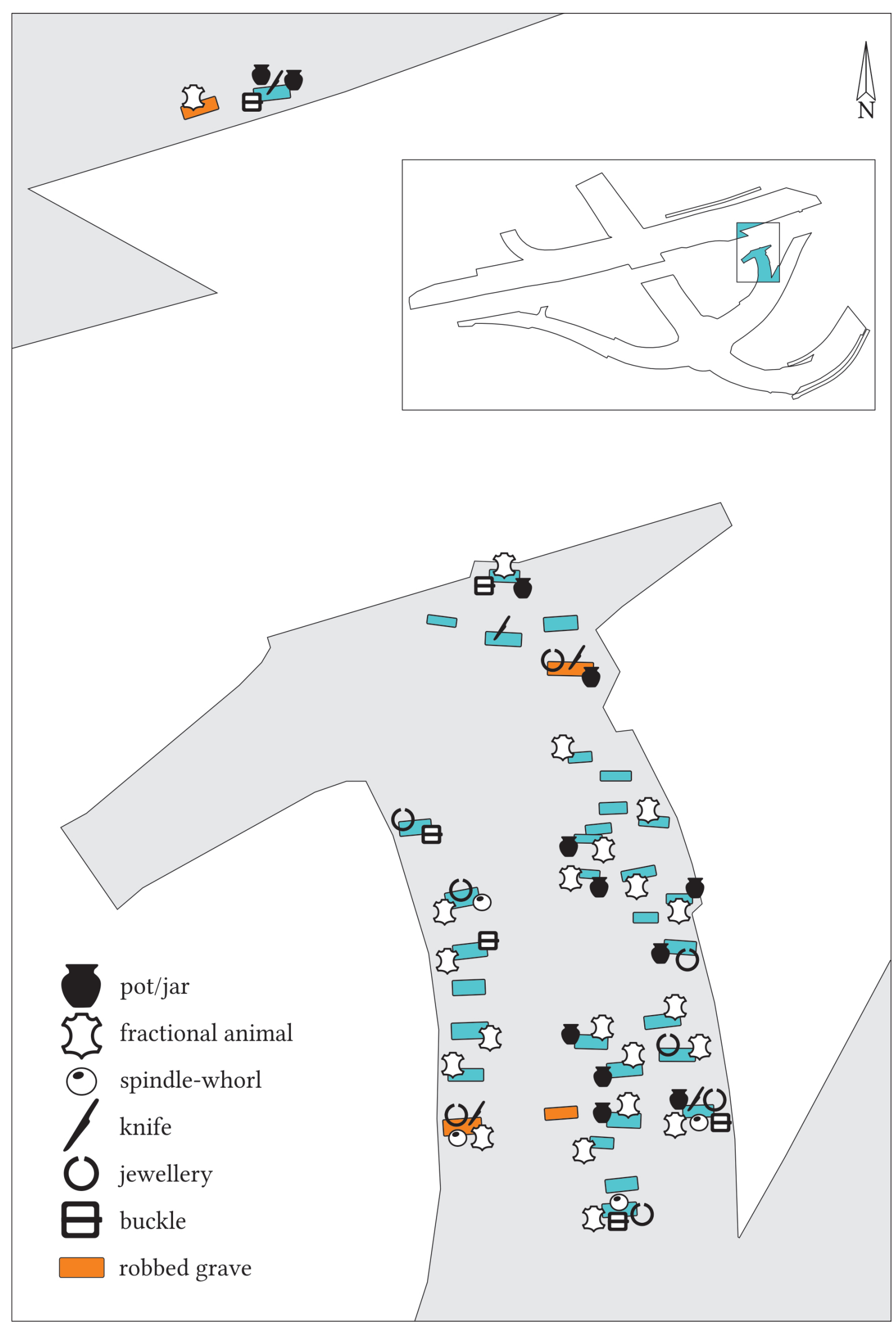

Fig. 10. The most frequent grave furnishing practices of the early Avar-period cemetery. 
However, in contrast with the early Avar-period graves, here the robbers not only dug onto the area of the head and the chest, but they also turned the entire skeleton over, and threw a part of the removed bones back into the robber pits.

The grave pits were deeper than those of the early period, their relative depth was 1.5-1.8 meter. Their structure can be commonly characterized by four postholes that sink into the bottom of the grave at the four corners. They were north-south-oriented, and as attested by the scattering of the grave goods that remained in the graves, the orientation of the deceased was also adjusted to this axis. Based on their position, it is obvious that only four graves constituted this group of graves.

Bones attesting to partial animal offerings could be assorted among the disturbed finds of two graves (Fig. 11). From among the bones of small ruminants, skull and jaw fragments, and limb bones came to light from the graves. Due to their secondary position, their original function cannot be determined.

Based on the strongly rusted iron objects found by the shorter sides of the grave pits, we may assume the use of coffins fastened by iron clamps.

There were only a few traces attesting to grave furnishing practices. Based on the bone plates yielded by one of the graves, a bow had also been buried with the deceased, placed onto the right side of the body (Fig. 11). There could be a pot by the feet. Despite the robbery, we found an inlaid gold ring in the area of

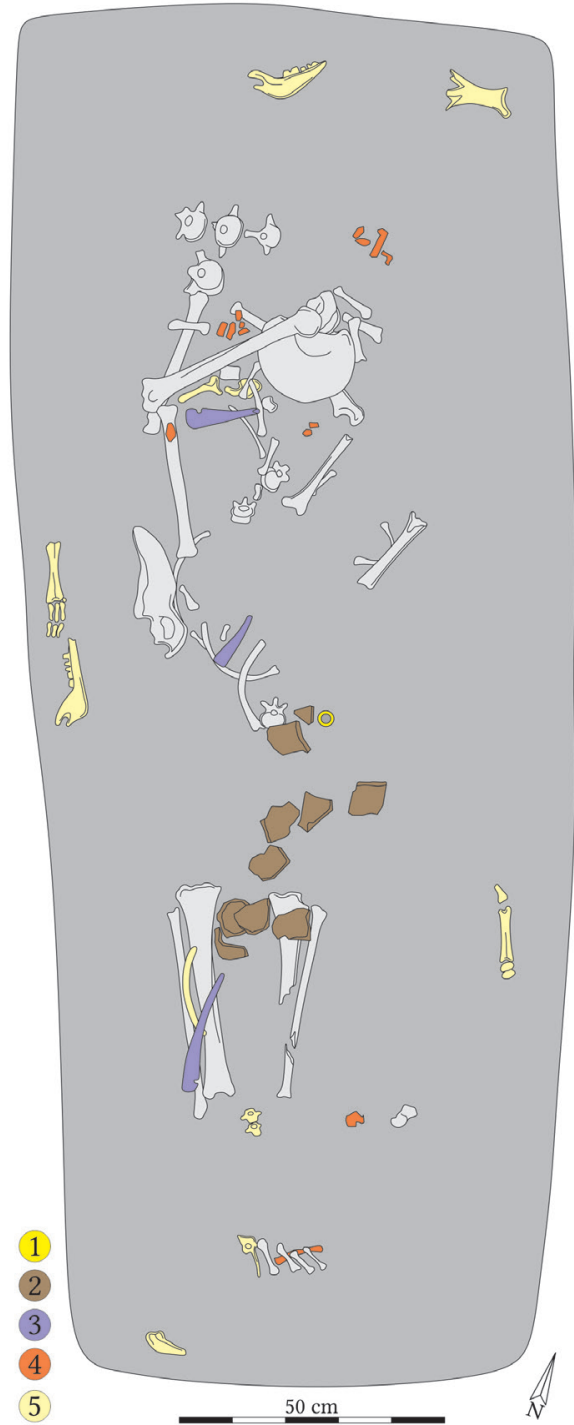

Fig. 11. A late Avar-period, robbed grave. 1 - gold ring, 2 - pot, 3 - bow, 4 - iron objects, 5 - animal bones the pelvis and the hands. In the case of the other late Avar-period grave that also contained grave goods, the ceramic vessel was laid by the northern wall of the grave. After the looting, only a lathe-turned bone needle-case remained in this grave besides the vessel.

\section{References}

Ács, Cs. 1992: Megjegyzések a késő szarmata kerámiakérdéséhez (Anmerkungen zur Frage der spätsarmatischen Keramik). A fósa András Múzeum Évkönyve 30-32 (1987-1989), 97-112.

Csengeri, P. - Pusztai, T. 2008: Császárkori germán település a Hernád völgyében (Germanic [Vandal] settlement of the Roman period from the Hernád Valley [Northeastern Hungary]). A Herman Ottó Múzeum Évkönyve 47, 89-106.

Domвoróczki, L. 2009: Settlement Structures of the Alföld Linear Pottery Culture (ALPC) in Heves County (North-Eastern Hungary): Development Models and Historical Reconstructions on Micro, Meso and Macro Levels. In: KozŁowski, J. K. (ed.): Interactions between different models of 
Neolithization north of the Central European Agro-Ecological Barrier. Prace Komisji Prehistorii Karpat PAU 5. Kraków, 75-127.

FüLöP, K. IN PRESS: The Birth of Wells. A Late Bronze Age Well from Pusztataskony-Ledence. In: Kiss, V. - Kulcsár, G. - V. Szabó, G. - VÁczi, G. (eds.): State of the Hungarian Bronze Age Research. Proceedings of the conference papers held between 17th and 18th of December 2014. Prehistoric Studies - Ösrégészeti Tanulmányok 2. in press.

FüZesi, A. - BArtus, D. - FÜlöp, K. - Juhász, L. - Rupnik, L. - Siklósi, Zs. - V. Szabó, G. - Szilágyi, M. VÁczI, G. 2015: Preliminary report on the field surveys and excavations in the vicinity of Berettyóújfalu. Dissertationes Archaeologicae 3/3, 223-239.

FüZesi, A. - FARAgó, N. - RAczky, P. 2017: Tiszaug-Railway-station. An archaic Middle Neolithic community on the Great Hungarian Plain. Dissertationes Archaeologicae 3/5, 7-65.

GABLER, D. 2012: Terra sigillaták Aquincum legkorábbi táborából és annak helyén emelt későbbi római épületekből (Samian ware from earliest fort of Aquincum). Budapest Régiségei 45, 111-150.

Gabler, D. - H. Vaday, A. 1986: Terra Sigillata im Barbaricum zwischen Pannonien und Dazien. Fontes Archaeologici Hungariae, Budapest.

GöNCZI F. 1905: Göcseji kutak és hácskuk. Néprajzi Értesitő 6, 6-11.

GuLYÁs, B. - LőRINCzY, G. 2018: Szabolcs-Szatmár-Bereg megye avar sírleletei IV. A tiszavasvári-koldusdombi kora avar kori temető (Avar finds from Szabolcs-Szatmár-Bereg County IV. Early Avar graves from Tiszavasvári-Koldusdomb). In: L. NAGY, M. - L. SzőıősI, K. (eds.): „Vadrózsából tündérsípot csináltam” Tanulmányok Istvánovits Eszter 60. születésnapjára („To make a fairy’s whistle from a briar rose" Studies presented to Eszter Istvánovits on her sixtieth birthday). A Jósa András Múzeum Kiadványai 73. Nyíregyháza, 529-569.

IstvÁnovits, E. 1999: Tiszavasvári-Városföldje, Jegyző-tag. A settlement of the 5th century (Hunkori település maradványai Tiszavasváriban, a Városföldjén). A fósa András Múzeum Évkönyve 41, $173-254$.

Istvánovits, E. 2015: A szarmaták állatai (Animals of Sarmatians). A fósa András Múzeum Évkönyve 57, 99-128.

KirÁLy, Á. - Tóth, K. 2015: Preliminary Report on the Middle Neolithic Well from Sajószentpéter (North-Eastern Hungary). Dissertationes Archaeologicae 3/3, 213-221.

Kulcsár, V. 1998: A Kárpát-medencei szarmaták temetkezési szokásai. Aszód, 1998.

LőRINCZY, G. 1998: Kelet-európai steppei népesség a 6-7. századi Kárpát-medencében. Régészeti adatok a Tiszántúl kora avar kori betelepüléséhez (Osteuropäische Steppenbevölkerung im 6. und 7. Jahrhundert im Karpatenbecken. Archäologische Beiträge zur frühawarenzeitlichen Einsiedlung des Gebites jenseist der Theiß). A Móra Ferenc Múzeum Évkönyve - Studia Archaeologica 4, 343-372.

LőRINCZY, G. 2016: A tiszántúli VI-VII. századi sírok és temetők sajátosságai. A kora avar kori népesség továbbélése a VII-IX. században a Körös-Tisza-Maros közén (Characteristic features of 6th7th century burials and cemeteries east of the Tisza Survival of Early Avarian Age population between Rivers Körös, Tisza and Maros). A fósa András Múzeum Évkönyve 57, 155-176.

MADARAS, L. 2004: Kora avar kori sírok Öcsödről (Frühawarenzeitliche Gräber in Öcsöd). A Móra Ferenc Múzeum Évkönyve - Studia Archaeologica 10, 339-363.

MelleR, H. - Knoll, F. - Filipp, J. 2013: Rot - vom Leben bis zum Tod. Prähistorische Rötel- und Hämatitfunde aus Mitteldeutschland. In: Meller, H. - Wunderlich, CH.-H. - Knoll, F. (Hrsg.): Rot - Die Archäologie bekennt Farbe. 5. Mitteldeutscher Archäologentag vom 4. bis 6. Oktober 2012 in Halle (Saale). Tagungen des Landesmuseums für Vorgeschichte Halle 10. Halle, 145-183.

NohÁlovÁ, H. - VÁvra J. - Kuchař́́K, M. 2006: Dog Burial and Animal Bone Remains from the Human Graves in Prague-Zličín. Interdisciplinaria Archaeologica - Natural Sciences in Archaeology 7, 71-86. 
Oravecz, H. 1998-1999: Middle Neolithic Burials at Tiszaföldvár. Data to the Burial customs and social relations of the Alföld Linearband Pottery Culture. Folia Archaeologica 47, 43-62.

Oross, K. - MARton, T. 2012: Neolithic Burials of the Linearbandkeramik settlement at Balatonszárszó and their European context. Acta Archaeologica Academiae Scientiarum Hungaicae 63, 257-300.

RAczky, P. 2006: House-structures under Changes on the Great Hungarian Plain in Earlier Phases of the Neolithic. In: TAsić, N. (ed.): Homage to Milutin Garašanin. SASA Special Edition. Belgrade, 379-398.

Siklósi, Zs. - Csengeri P. 2011: Reconsideration of Spondylus usage in the Middle and Late Neolithic of the Carpathian Basin. In: Ifantidis, F. - Nikolaidou, M. (eds.): Spondylus in Prehistory. New Data and Approaches. Contributions to the Archaeology of Shell Technologies. British Archaeological Reports - International Series 2216, Oxford, 47-62.

SzILÁgyi, M. - Fülöp, K. - RÁkos, E. - Szabó, N. 2017: Rescue excavations in the vicinity of Cserkeszőlő (Jász-Nagykun-Szolnok county, Hungary) in 2017. Dissertationes Archaeologicae 3/5, 393-399.

Tegel, W.- Elburg, R.- Hakelberg, D.- Stäuble, H.- Büntgen, U. 2012: Early Neolithic Water Wells Reveal the World's Oldest Wood Architecture. PLoS ONE 7/12. e51374. doi:10.1371/journal.pone.0051374.

VADAY, A. 1997: Atipikus szarmata telepjelenség a Kompolt-Kistéri Tanya 15. Lelőhelyen (Eine atypische sarmatische Siedlungserscheinung auf dem Fundort Kompolt, Kistéri-Gehöft 15). Agria Az Egri Múzeum Évkönyve 33, 77-107.

WeINER, J. 2012: Bandkeramische Brunnen - Ausnahmebefunde oder Standardinstallationen zur Wasserversorgung? In: Klimscha, F. - Eichmann, R. - Schuler, Ch. - Fahlbusch, H. (eds.): Wasserwirtschaftliche Innovationen im archäologischen Kontext. Von den prähistorischen Anfängen bis zu den Metropolen der Antike. Menschen - Kulturen - Tradtionen Band 5, ForschungsCluster 2 Innovationen: technisch, sozial. Rahden/Westf., 83-92.

Whittle, A. - Anders, A. - Bentley, R. A. - Bickle, P. - Cramp, L. - Domboróczki, L. - Fibiger, L. Hamilton, J. - Hedges, R. - Kalicz, N. - Kovács, E. Zs. - Marton, T. - Oross, K. - Pap, I. Raczky, P. 2013: Hungary. In: Bickle, P. - Whittle, A. (eds.): The First Farmers of Central Europe. Diversity of LBK Lifeways. Oxford-Oakville, 49-100. 